Author version: Marine Biology Research, vol.8; 2012; 677-681

\title{
$70 \mathrm{kD}$ stress protein (Hsp70) analysis in living shallow-water benthic foraminifera
}

PETRA HEINZ ${ }^{1}$, ROMAN A. MARTEN ${ }^{1}$, VALIYAPARAMBIL N. LINSHY ${ }^{2}$, TIMO HAAP ${ }^{3}$, EMMANUELLE GESLIN ${ }^{4}$, HEINZ-R. KÖHLER ${ }^{3}$

${ }^{1}$ Department for Geosciences, University of Tübingen, Hölderlinstr. 12, 72074 Tübingen, Germany

${ }^{2}$ Micropaleontology Laboratory, National Institute of Oceanography, CSIR, Dona Paula, Goa-403 004, India

${ }^{3}$ Animal Physiological Ecology, Institute of Evolution and Ecology, University of Tübingen, KonradAdenauer-Str. 20, 72072 Tübingen, Germany

${ }^{4}$ Laboratoire d'Etude des Bio-indicateurs Actuels et Fossiles (BIAF) and LEBIM, University of Angers, 2 Boulevard Lavoisier, 49045 Angers Cedex, France

* Correspondence: Petra Heinz, Department for Geosciences, University of Tübingen, Hölderlinstr. 12, 72074 Tübingen, Germany. E-mail: petra.heinz@uni-tuebingen.de

\begin{abstract}
Hsp70 is a phylogenetically highly conserved protein family present in all eukaryotic organisms tested so far. Its synthesis is induced by proteotoxic stress. The detection of Hsp70 in foraminifera is presented here for the first time. We introduce a standard immunoblotting protocol modified for the detection of Hsp70 in shallow water benthic foraminifera. Additionally, we showed a temperature-dependent expression pattern of Hsp70 in Ammonia tepida.
\end{abstract}

Key words: foraminifera, benthos, heat shock proteins, HSP 70, protein content 


\section{Introduction}

In stressful situations (like elevated temperatures), many organisms strongly increase the production of stress proteins or heat shock proteins (=Hsps), that bind to partially denatured proteins preventing their aggregation, and directly mediate the correct folding (Gething and Sambrook 1992, Parsell and Lindquist 1993). Members of the class of Hsps have been found in all eukaryotic organisms tested thus far (Lindquist and Craig 1988). These proteins are phylogenetically highly conserved, especially the Hsp70-family (Gupta and Golding 1993). They can be used as biomarkers to monitor physiological stress caused by changing environmental conditions or pollution (e.g. Köhler et al. 1996). The aim of this study is to verify the existence of Hsp70 in foraminifera. Therefore, a standard protocol for immunological detection of Hsp70 (Köhler et al. 2005) was optimized for these organisms. Total protein contents of different foraminiferal species (Ammonia beccarii Linnaeus, 1758, Ammonia tepida Cushman, 1926, Elphidium crispum Linnaeus, 1758, and Massilina secans d'Orbigny, 1826) were determined, which can help to estimate the number of individuals needed for immunological studies.

\section{Material and methods}

\section{Sediment Samples}

Field sediments containing Massilina secans, Ammonia beccarii and Elphidium crispum were collected on the rocky shore near the Laboratory of Marine Bio-Indicators (LEBIM) on Yeu Island (France) in July 2007 and May 2008. Ammonia tepida was collected in the muddy shore in the Bay of Aiguillon (France) in June 2008. At both stations, the surface sediment was collected with a spoon and sieved; the $>150 \mu \mathrm{m}$ fraction was transferred to transport boxes (250 ml PE bottles, Kautex, Bonn, Germany) and carried to our lab in Tübingen, Germany.

\section{Foraminifera Treatment, Protein Extraction and Concentration}

In the laboratory the sediment was transferred to $2 \mathrm{~L}$ glass aquaria. Aquaria were kept under stable conditions $\left(20^{\circ} \mathrm{C}, 34 \%\right.$ salinity, $11: 13 \mathrm{~h}$ light-dark cycle) up to 4 months in order to acclimate the foraminifera to laboratory condition. Sediment subsamples were shortly washed, and living foraminifera were picked and cleaned from small particles with a fine brush in an embryo dish filled with filtered seawater. The foraminifera were transferred into glass vessels filled with $100 \mathrm{ml}$ seawater and sealed with parafilm. For a possible induction of stress proteins, vessels were placed in incubators adjusted to 
higher $\left(\max .45^{\circ} \mathrm{C}\right)$ or lower temperatures, or left at control conditions at $20^{\circ} \mathrm{C}$. The experimental setups are summarized in Table 1.

For the extraction of the proteins, foraminifera were taken out of the vessels, and transferred with the smallest possible amount of water to a $1.5 \mathrm{ml}$ Eppendorf cup. Extraction buffer $(80 \mathrm{mM}$ potassium acetate, $5 \mathrm{mM}$ magnesium acetate, $20 \mathrm{mM}$ Hepes $\mathrm{pH} \mathrm{7.5)}$ and protease inhibitor (Protease Inhibitor Cocktail, product no. P8340, Sigma, St. Louis, Missouri, USA) were added, and the foraminifera were mechanically homogenized with a plastic pestle. To remove the shell fragments the homogenate was centrifuged at $4^{\circ} \mathrm{C}$ at $153 \mathrm{~g}$ for 10 minutes and the supernatant was transferred to a new vial. A $4 \mu 1$ aliquot of the supernatant was reserved for quantification of total protein content. The rest of the supernatant was mixed with sodium dodecyl sulfate (SDS) -containing buffer (20\% glycerol, 3\% SDS, $0.3 \% \beta$-mercaptoethanol, $10 \mathrm{mM}$ Tris $\mathrm{pH} 7$ ) in the ratio 2:1 (two parts supernatant : one part buffer), heated to $100^{\circ} \mathrm{C}$ for five minutes, and kept for further analysis at $-20^{\circ} \mathrm{C}$. For the protein concentration after extraction we used ultrafiltration units for centrifuges (Roti®-Spin Mini-30, Roth, Karlsruhe, Germany) with a nominal molecular weight cut off of $30 \mathrm{kDa}$ and centrifuged the samples (experiment I: $5 \mathrm{~min}$ at 5,000 g; experiment II: $9 \mathrm{~min}$ at 4,000 g). During centrifugation, all proteins larger than 30 kDa pass through the filter, and Hsp70 can accumulate in the supernatant.

\section{Bradford Assay}

Due to the detection range of the analysis, the Bradford analysis had to be conducted prior to sample ultrafiltration. The total protein content was measured two times per sample. For each measurement $2 \mu 1$ of the protein solution together with $23 \mu \mathrm{l}$ of extraction buffer 1:10 were transferred to a 96-well microplate. For the standard curve a serial dilution of bovine serum albumin (BSA) $(0.4,0.2,0.1,0.05$, $0.025 \mathrm{mg} / \mathrm{ml}$ ) in extraction buffer 1:10 was used. Subsequently $250 \mu \mathrm{l}$ of Bradford reagent was added to each well. Measurements were made with an automated microplate reader (Elx 8006, BioTek, Winooski, Vermont, USA).

\section{Immunological Analysis}

Immunological analysis followed the protocol of Köhler et al. (2005). Extracted proteins were analyzed by minigel SDS-PAGE $(12 \%$ acrylamide $(\mathrm{w}=\mathrm{v}), 15 \mathrm{~min}$ at $80 \mathrm{~V}$ and $90 \mathrm{~min}$ at $120 \mathrm{~V})$. Protein was

transferred to nitrocellulose by semi-dry blotting (Western blotting after Burnette 1981), and the filter 
was blocked for $2 \mathrm{~h}$ in 50\% horse serum in TBS (50 mM Tris pH 7.5, $150 \mathrm{mM} \mathrm{NaCl})$. After washing in TBS, either (a) the monoclonal antibody "mouse anti-human Hsp70 (MA3-006)"; Dianova, Hamburg, Germany, dilution 1:5000, or, alternatively, (b) the monoclonal antibody "mouse anti-chicken Hsp70/Hsc70 (SPA-822)"; Dianova, dilution 1:1000 (experiment II), or (c) a combination of both antibodies in the given concentrations (experiment I) was added. The filter was then incubated on a lab shaker at room temperature overnight.

After repeated washing in TBS for $5 \mathrm{~min}$, the nitrocellulose filter was incubated with the secondary antibody solution (goat anti-mouse IgG coupled to peroxidase, Dianova, dilution 1:1000 in 10\% horse serum in TBS) for $2 \mathrm{~h}$ at room temperature. After subsequent TBS washing, the antibody complex was detected by the staining solution ( $1 \mathrm{mM}$ 4-chloro(1)naphthol and $0.015 \% \mathrm{H}_{2} \mathrm{O}_{2}$ in $30 \mathrm{mM}$ Tris $\mathrm{pH} 8.5$ containing $6 \%$ methanol).

To quantify the amount of protein in the bands, the optical volumes (area (number of pixels) x average grey scale value) of the protein bands in experiment I were measured after background subtraction with a densitometric image analysis system (Herolab E.A.S.Y.). For comparison, the optical volumes were normalized by dividing them through the amount of total protein transferred to each lane.

\section{Results}

\section{Protein Contents}

Protein concentrations were quantified by the Bradford test. For each species, the mean total protein content per individual was calculated (Table 2). Highest protein content per individual $(0.231 \mu \mathrm{g})$ was extracted from $M$. secans, followed by A. beccarii $(0.085 \mu \mathrm{g})$, A. tepida $(0.066 \mu \mathrm{g})$ and E. crispum (0.040 $\mu \mathrm{g})$.

\section{Hsp70-Immunoassay}

One first weak band of foraminiferal Hsp70 was detected when 386 individuals of M. secans, 357 individuals of $A$. beccarii, and 300 individuals of E. crispum were pooled together and incubated for $3 \mathrm{~h}$ at $39^{\circ} \mathrm{C}$. We transferred $47 \mu \mathrm{g}$ total protein to the gel, limited by the size of the gel pockets. After including an additional step of protein concentration by ultrafiltration, we were able to increase the 
amount of total protein $(>30 \mathrm{kD})$ on the gel. This modification significantly enhanced detection of Hsp70.

\section{Temperature Expression}

In experiment I, four pools of foraminifera were prepared and exposed to different stress temperatures: $10^{\circ} \mathrm{C}, 20^{\circ} \mathrm{C}, 35^{\circ} \mathrm{C}$, and $45^{\circ} \mathrm{C}$ (Table 1). Proteins were extracted and concentrated. Expressed Hsp 70 was shown in Fig. 1. At $45^{\circ} \mathrm{C}$, no Hsp70-band was visible (Fig. 1, lane 4) and no intact proteins were detected by the Bradford test (Table 1). The amount of total extracted proteins (Table 1) and therefore of concentrated proteins $(>30 \mathrm{kD})$ loaded in the different lanes was not equal. In order to normalize the results, the optical volumes of lanes 1-4 were divided through the corresponding transferred protein mass (Fig. 2). The amount of detected Hsp70 was lowest at $20^{\circ} \mathrm{C}$ (adequate to normal "unstressed" culture temperature), followed by $10^{\circ} \mathrm{C}$, and a maximum was found at $35^{\circ} \mathrm{C}$.

\section{Antibody Test}

The cross-reactivity of the different primary antibodies used in the previous samples and the quality of the concentration step after extraction was tested in experiment II. Concentrated foraminiferal protein $(>30 \mathrm{kD})$ was tested with each of the both primary antibodies used. The antibody "mouse anti-human Hsp70 (MA3-006)“ detected a band of Hsp70, the antibody "mouse anti-chicken Hsp70/Hsc70 (SPA822)" did not detect any band, also no standard was visible here. To check if there was a major loss of Hsp70 during ultrafiltration, the filtrate (containing proteins $<30 \mathrm{kD}$ ) was also analyzed. No Hsp70 could be detected in the filtrate with neither of the two primary antibodies.

\section{Discussion}

\section{Hsp70-Immunoassay}

About $50 \mu \mathrm{g}$ total protein is needed to detect Hsp70 in foraminifera by immunoblotting, which is remarkably more than used in the majority of studies dealing with other organisms (e.g. Knigge and Köhler 2000, Köhler et al. 2000). This could be explained by a considerably increased level of other essential proteins in foraminiferal cells, like actin and tubulin, which then lead to a proportionally low concentration of Hsp70 in the cytoplasm. Actin and tubulin are basic components of the cytoskeleton. Pseudopodial movement and the high dynamic cytoplasm motility of foraminifera need the presence of 
many microfilaments composed of these two proteins (Travis and Bowser 1986). Another reason might be a low cross-reactivity of the used primary antibodies to bind to foraminiferal Hsp70, although our tested antibodies were developed to bind a large variety of Hsp70 proteins, as the target epitope of the amino acid sequence for the antibody to bind is located in the highly conservative ATP-binding region of the protein.

\section{Temperature Expression}

Experiment I investigated the relationship between stress temperature and expression of the Hsp70 protein (Fig. 1). Four pools of A. tepida (in total more than 5000 living foraminifera) were collected and exposed to different temperatures. The number of available foraminifera and the time-consuming process of isolating these out of the sediment limited the number of temperature steps. Because we decided to transfer the maximum amount of total extracted protein $(>30 \mathrm{kD})$ of each pool to enhance Hsp70 detection, the amount of protein transferred to the different lanes differs and had to be normalized for comparison (Fig. 2).

The expression of $\mathrm{Hsp} 70$ was highest at $35^{\circ} \mathrm{C}$. At a culture temperature of $20^{\circ} \mathrm{C}$ almost no Hsp 70 was found, but at $10^{\circ} \mathrm{C}$ the Hsp70 had increased again. These results fit very well to the established statement that denaturated proteins caused by physiological stress, which can be created by higher temperatures as well as lower temperatures (Creighton 1990), induce Hsp70. The results also match to the Hsp70 reaction curve of Eckwert et al. (1997), showing the relationship of stress intensity and Hsp70 level.

No Hsp70 was detected at $45^{\circ} \mathrm{C}$. Bradshaw (1961) determined the lethal temperature for A. tepida at $45^{\circ} \mathrm{C}$, in which $50 \%$ of exposed specimens have been killed within 5 minutes. Our organisms have been exposed to this temperature for 4 hours, therefore we suppose that they did not survive and the proteins have likely been disintegrated.

\section{Antibody Test}

In the advanced experiment II either the MA3-006 was used as the first antibody, or SPA-822. Therefore, it was possible to judge on their respective potential to cross-react with foraminiferan antigen hsp70 of A. tepida, which would not have been possible, if the antibodies were applied as a mixture of them (experiment I). Since SPA-822 did not show any cross-reactivity with foraminiferan Hsp70, we 
assume that the signals obtained in experiment I derive from MA3-006 cross-reaction solely. It was not possible to detect any Hsp70 in the filtrate after microfiltration with both antibodies. Therefore, we can assume that no or only a negligible amount of Hsp70 proteins were lost during filtration.

\section{Acknowledgments}

We would like to thank Vera Hemleben for her valuable ideas on the improvement of our method, and Michal Kucera and Ralf Aurahs for their help at an early stage of the manuscript. The authors are grateful to Stefanie Krais for technical support and Annekatrin Enge for her help to obtain the sample material. Particular thanks are due to Christina Beal for linguistic improvements.

\section{References}

Bradshaw JS. 1961. Laboratory experiments on the ecology of foraminifera. Journal of Foraminiferal Research 12:87-106.

Burnette WN. 1981. "Western blotting": Electrophoretic transfer of proteins from sodium dodecyl sulfate-polyacrylamide gels to unmodified nitrocellulose and radioionated protein A. Analytical Biochemistry 112:195-203.

Creighton TE. 1990. Protein folding. Biochemical Journal 270:1-16.

Eckwert H, Alberti G, Köhler H-R. 1997. The induction of stress proteins (hsp) in Oniscus asellus (isopoda) as a molecular marker of multiple heavy metal exposure. I. Principles and toxicological assessment. Ecotoxicology 6:249-62.

Gething MJ, Sambrook J. 1992. Protein folding in the cell. Nature 355: 33-45.

Gupta RS, Golding GB. 1993. Evolution of hsp70 gene and its implications regarding relationships between archaebacteria, eubacteria, and eukaryotes. Journal of Molecular Evolution 37:573-82.

Knigge T, Köhler H-R. 2000. Lead impact on nutrition, energy reserves, respiration and stress protein (hsp 70) level in Porcellio scaber (isopoda) populations differently preconditioned in their habitats. Environmental Pollution 108: 209-17.

Köhler H-R, Rahman, B, Gräff S, Berkus M, Triebskorn R. 1996. Expression of the stress-70 protein family (hsp70) due to heavy metal contamination in the slug, Deroceras reticulatum: An approach to monitor sublethal stress conditions. Chemosphere 33:1327-40. 
Köhler H-R, Bartussek C, Eckwert H, Farian K, Gränzer S, Knigge T, Kunz N. 2000. The hepatic stress protein (hsp70) response to interacting abiotic parameters in fish exposed to various levels of pollution. Journal of Aquatic Ecosystem Stress and Recovery 8:261-79.

Köhler H-R, Alberti G, Seniczak S, Seniczak A. 2005. Lead-induced hsp70 and hsp60 pattern transformation and leg malformation during postembryonic development in the oribatid mite, Archegozetes longisetosus aoki. Comparative Biochemistry and Physiology Part C: Pharmacology Toxicology and Endocrinology 141:398-405.

Lindquist S, Craig EA. 1988. The heat-shock proteins. Annual Review of Genetics 22:631-77.

Parsell DA, Lindquist S. 1993. The function of heat-shock proteins in stress tolerance - degradation and reactivation of damaged proteins. Annual Review of Genetics 27:437-96.

Travis JL, Bowser SS. 1986. Microtubule-dependent reticulopodial motility - is there a role for actin? Cell Motility and the Cytoskeleton 6:146-52. 


\section{Tables}

Table 1. Overview of experimental conditions: assemblages of foraminifera/standards, duration and temperature of heat stress, primary antibodies, and amount of extracted total protein (analysis before ultrafiltration). Primary antibodies: "mouse anti-human Hsp70 (= MA3-006)", "mouse anti-chicken Hsp70/Hsc70 (= SPA-822)".

\begin{tabular}{|c|c|c|c|c|}
\hline Experiment & Specimen & Stress & $\begin{array}{l}\text { Primary } \\
\text { antibody }\end{array}$ & $\begin{array}{c}\text { Total } \\
\text { protein }(\mu \mathrm{g})\end{array}$ \\
\hline \multirow[t]{5}{*}{ I } & 1,300 A. tepida & $4 \mathrm{~h} / 10^{\circ} \mathrm{C}$ & MA3-006 & 77.9 \\
\hline & 1,300 A. tepida & $4 \mathrm{~h} / 20^{\circ} \mathrm{C}$ & + SPA-822 & 106.0 \\
\hline & 1,300 A. tepida & $4 \mathrm{~h} / 35^{\circ} \mathrm{C}$ & & 79.8 \\
\hline & 1,300 A. tepida & $4 \mathrm{~h} / 45^{\circ} \mathrm{C}$ & & -- \\
\hline & D. rerio (standard) & & & 40.0 \\
\hline \multirow[t]{6}{*}{ II } & D. rerio (standard) & & MA3-006 & 40.0 \\
\hline & D. rerio (standard) & & SPA-822 & 40.0 \\
\hline & 1,057 A. tepida & $4 \mathrm{~h} / 35^{\circ} \mathrm{C}$ & MA3-006 & 57.9 \\
\hline & 1,057 A. tepida & $4 \mathrm{~h} / 35^{\circ} \mathrm{C}$ & SPA-822 & 57.9 \\
\hline & filtrate & $4 \mathrm{~h} / 35^{\circ} \mathrm{C}$ & MA3-006 & - \\
\hline & filtrate & $4 \mathrm{~h} / 35^{\circ} \mathrm{C}$ & SPA- 822 & - \\
\hline
\end{tabular}


Table 2. Average total protein content per individual of the different species ( $\mathrm{SD}=$ standard deviation).

\begin{tabular}{cccc}
\hline Species & $\begin{array}{c}\text { Number of } \\
\text { measurements }\end{array}$ & $\begin{array}{c}\text { Total number of } \\
\text { specimen }\end{array}$ & $\begin{array}{c}\text { Total protein } \\
\text { per individual (SD) }(\mu \mathrm{g})\end{array}$ \\
\hline A. tepida & 4 & 7,070 & $0.066(0.012)$ \\
M. secans & 3 & 315 & $0.231(0.034)$ \\
A. beccarii & 1 & 370 & $0.085(-)$ \\
E. crispum & 1 & 600 & $0.040(-)$ \\
\hline
\end{tabular}




\section{Figure Legends}

Figure 1. Temperature depending expression pattern of A. tepida (experiment I). Immunodetection of Hsp70 by Western blotting. antibodies: MA3-006 + SPA-822. Lane 1-4: A. tepida, lane 5: Standard (D. rerio).

Figure 2. Temperature depending expression pattern of A. tepida (experiment I). Hsp70 level was quantified by optical volume of the bands on the resulting filter with a densitometric image analysis system (Herolab E.A.S.Y.) and normalized with the amounts of total protein transferred to each lane. 
Heinz et al.

Figure 1

$\begin{array}{lllll}1 & 2 & 3 & 4 & 5\end{array}$

$10^{\circ} \mathrm{C} \quad 20^{\circ} \mathrm{C} \quad 35^{\circ} \mathrm{C} \quad 45^{\circ} \mathrm{C} \quad$ Standard 
Heinz et al.

Figure 2

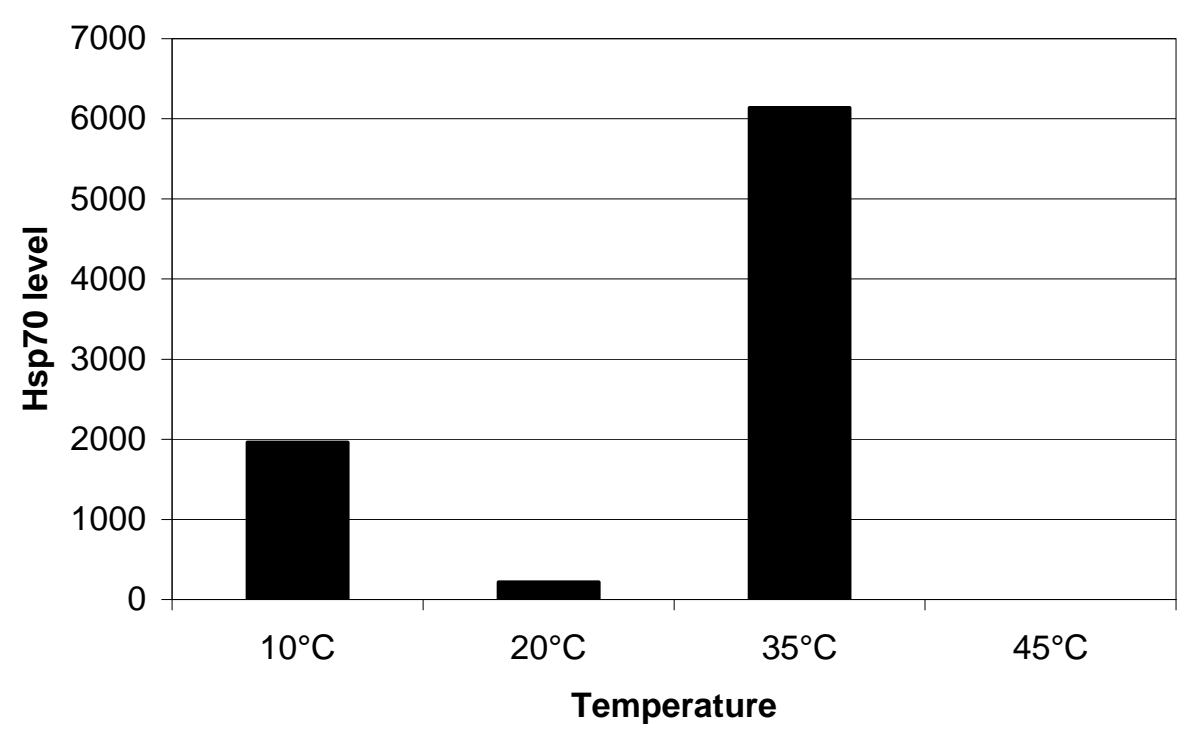

